\title{
COSMETIC PRODUCTS CONTAINING NATURAL BASED EMOLLIENTS FOR RESTORING IMPAIRED SKIN BARRIER: FORMULATION AND IN VIVO EVALUATION
}

\author{
MIRELA LILIANA MOLDOVAN *, IULIA IONUȚ, CĂTĂLINA BOGDAN \\ Department of Dermopharmacy and Cosmetics, Faculty of Pharmacy, "Iuliu Hațieganu” University of Medicine and
} Pharmacy, 12 I. Creangă Street, 400010, Cluj-Napoca, Romania

*corresponding author: mmoldovan@umfcluj.ro

Manuscript received: June 2020

\begin{abstract}
The skin barrier helps to protect the skin against external harmful factors and to prevent the excessive water loss. Numerous extrinsic and intrinsic factors may impair the skin barrier, leading to dry and damaged skin. The aim of this study was the development of two cosmetic creams for restoring the integrity of the epidermal barrier. Persea americana fruit oil, Oenothera biennis oil, Vitellaria paradoxa butter were chosen as natural based emollients. Subsequently, viscosity and texture analysis of the creams were determined and the efficacy evaluation through biophysical measurements was carried out on human volunteers. The results of hydration level and transepidermal water loss (TEWL) showed an improvement in skin barrier function, as both parameters were significantly increased following a four-week application period. Volunteers have experienced an improvement in the appearance of the skin, which encourages the long-term use of the products, a necessary condition to improve the skin barrier function.
\end{abstract}

\section{Rezumat}

Funcția de barieră a pielii asigură protecția acesteia împotriva agresiunilor externe și previne deshidratarea excesivă. Perturbarea funcției de barieră a pielii, sub acțiunea factorilor extrinseci sau intrinseci este asociată cu pielea uscată și degradată. Obiectivul acestui studiu a fost dezvoltarea a două creme cosmetice pentru refacerea funcției de barieră a pielii. Ca emolienți naturali s-au selectat uleiul din fructe de Persea americana, uleiul de Oenothera biennis și untul de Vitellaria paradoxa. S-a studiat vâscozitatea cremelor și profilul de textură ale acestora, iar efectul cremelor formulate a fost evaluat pe voluntari pe durata a patru săptămâni. Rezultatele nivelului de hidratare și pierderea transepidermică de apă (TEWL) au evidențiat o îmbunătățire a funcției de barieră a pielii, deoarece ambii parametri au fost influențați pozitiv. Voluntarii au raportat o îmbunătățire a aspectului pielii, fapt care încurajează utilizarea pe termen lung, pentru îmbunătățirea funcției de barieră a pielii.

Keywords: skin barrier, natural based emollients, skin hydration, TEWL, in vivo test

\section{Introduction}

Skin as the outermost organ of the body has a protection role, acting as a physical, chemical, biochemical and immunological barrier. Currently, it is commonly accepted than the skin barrier is represented mainly by the stratum corneum (SC). Its contribution to a functional barrier is ensured through its main constituents, the corneocytes and the intercellular lipids, its specific arrangement as a part of the typical two-compartmental "bricks and mortar" model and the corneodesmosomes providing the intercorneocytes adhesion. The cornified envelope of the corneocytes consists of various proteins, of which the filaggrin has the largest contribution to skin barrier. When reaches the skin surface, fillagrin breaks down into smaller molecules that form the natural moisturizing factor (NMF), a hygroscopic complex with an important role in the maintenance of the moisture content of SC $[6,13,14]$. Epidermal lipids also called physiological lipids, are located in the extracellular space and play an important role in the barrier function through a particular composition (50\% ceramides, $25 \%$ cholesterol and cholesterol esters and $15 \%$ free fatty acids) and through their specific molecular organisation as lamellar bilayers. Another major component of the skin barrier is the water-lipid mantle, a natural emulsion at the skin surface. This consists of water and sebaceous lipids (47\% fatty acids, $17 \%$ wax esters, $13 \%$ ceramides, $11 \%$ squalene, $7 \%$ cholesterol, $3 \%$ triglycerides, $2 \%$ cholesterol esters) $[6,15]$.

Water content of the skin influences the elasticity and the appearance of the skin, but also the biological function of several enzymes (glycosidase and serineproteases) involved in various physiological processes as corneosome degradation or enzymatic degradation of filaggrin. Low levels of water in SC disturb the desquamation process, being correlated with several skin conditions such as ichthyosis and xerosis. Low environmental humidity induces the release of proinflammatory mediators such as interleukin-1. This 
may be related to the aggravation of several inflammatory skin disorders in dry environmental conditions [6, 20]. Preventing skin dryness and maintaining the skin barrier homeostasis is the key to healthy and younger looking skin. For this purpose, an adequate skincare may have beneficial results. Among skincare products, emollients contribute to skin moisturization and improve skin condition, when they are used properly [5, 8, 20]. Emollient ingredients are able to reinforce lipid barrier function, to adjust the hydration level of SC and thus to improve different skin conditions [3, 13, 14, 20]. Emollient products usually contain occlusive ingredients, such as paraffin oil and petrolatum to decrease water loss, inducing the recovery of epidermal barrier along with intensive protection. Non-physiologic lipids form a hydrophobic layer at skin surface and do not penetrate beneath SC leading to a rapid decrease of TEWL values. Key physiologic lipids, free fatty acids, ceramides and cholesterol, added in optimal molar ratios are able to modulate epidermal lipid biosynthesis. Thus, the complementary mechanism of physiologic and nonphysiologic lipids can be used as an emerging concept in single formulations to develop efficient emollient products for barrier recovery $[8,10,11,15]$.

Besides lipid emollients, humectants are added to formulations to attract and retain water into SC. Glycerol is a widely used humectant due to its multiple activities, thoroughly described elsewhere. Particularly glycerol plays an important role in maintaining the appropriate osmolarity in the intracellular environment and the liquid crystalline structure of the membranes. Moreover, glycerol favours the cohesion of intercellular lipids, being also involved in the desquamation and skin renewal process by stimulating the digestive activity of desmosomes [12, 15, 26]. A combined approach based on the appropriate choice of humectants and emollients may provide optimal skin barrier benefits.

Niacinamide is a key ingredient for the maintenance and restoration of the skin barrier. Among many effects, niacinamide stimulates the synthesis of epidermal skin barrier lipids (mainly ceramides) and proteins (keratin, involucrin and filaggrin), but also represents a metabolic oscillator for circadian rhythms regulation of the skin barrier and a stimulator of the keratinocyte proliferation leading to a faster wound healing [2]. The aim of this study was the development of two semisolid topical formulations for restoring the integrity of the epidermal barrier, including vegetable oils with a high content of polyunsaturated acids. Evening primrose oil (Oenothera biennis seed oil), avocado oil (Persea americana fruit oil) and shea butter (Vitellaria paradoxa butter) were chosen as natural based emollients. Occlusive agents (cholesterol and beeswax) were added to inhibit TEWL. Glycerol was added for its humectant properties and niacinamide for the ability to enhance barrier function through multiple mechanisms. The first cream was formulated as oil-in-water gel-cream $(\mathrm{O} / \mathrm{W})$ and the second as a cold-cream water-in-oil dispersion (W/O). Subsequently, restructuring and hydrating properties were in vivo evaluated through biophysical measurements, during a four-week application period.

\section{Materials and Methods}

\section{Materials}

Depending on their spreadability and occlusive properties, different types of emollients were used: shea butter (from the nut of Vitellaria paradoxa), white beeswax (purchased from Elemental ${ }^{\circledR}$, Romania) and paraffin oil (Aiglon Group, France) as film-forming agents; an emollient with medium spreadability: caprilic/capric triglycerides (Coptis ${ }^{\mathrm{TM}}$, France) and two emollients with low spreading properties: cetostearyl alcohol and cetyl palmitate (Vitamar, Romania). Several emulsifying agents were chosen: cholesterol, glyceryl stearate (Vitamar, Romania), Ceteareth-6 and Ceteareth25 (Coptis $^{\mathrm{TM}}$, France). The other materials used were the following: Sepigel 305 (polyacrylamide\& C13-14 isoparaffin\&laureth-7, Seppic France), Euxyl 9010 (phenoxyethanol \& ethylhexylglycerin, Schülke \& Mayr GmbH, Germany), glycerol, sodium tetraborate and magnesium sulphate (Vitamar, Romania), avocado oil (Persea americana fruit oil), evening primrose oil (Oenothera biennis oil) and niacinamide (Elemental ${ }^{\circledR}$, Romania).

\section{Methods}

\section{Cream preparation}

Preparation of $\mathrm{O} / \mathrm{W}$ cream. The lipophilic ingredients (cetostearyl alcohol and cetyl palmitate, shea butter) were melted on a water bath at $60 \pm 2{ }^{\circ} \mathrm{C}$, together with the liposoluble emulsifier glyceryl stearate. After removing the melted mixture from the water bath avocado oil, caprylic/capric triglycerides and evening primrose oil were added. Ceteareth-25 was dissolved in water at $60 \pm 2{ }^{\circ} \mathrm{C}$, then niacinamide and glycerol were gradually added and the blend was progressively incorporated into Sepigel 305. The melted lipophilic phase was gradually added under continuous stirring at 2000 rpm (homogeniser Velp Scientifica ${ }^{\circledR}$, Italy), until a homogeneous product was obtained, and the cream reached the room temperature.

Preparation of W/O cream. The lipophilic ingredients (white beeswax, paraffin oil) were melted on a water bath at $70 \pm 2^{\circ} \mathrm{C}$, together with liposoluble emulsifiers cholesterol and Ceteareth- 6 then the melted mixture was removed from the water bath and shea butter was added, then avocado oil and evening primrose oil. Niacinamide, sodium tetraborate and magnesium sulphate were dissolved in water at $60 \pm 2^{\circ} \mathrm{C}$, then glycerol was added and this blend was progressively dispersed into the melted lipophilic phase under stirring at $2000 \mathrm{rpm}$, until a homogeneous product was obtained and the cream reached the room temperature. During the preparation process, another emulsifier is formed by saponification of free fatty 
FARMACIA, 2021, Vol. 69, 1

acids from beeswax with sodium hydroxide obtained from the hydrolysis of sodium tetraborate, contributing along with magnesium sulphate to the stabilization of the disperse system.

The composition of the two formulations is presented in Table I.

Table I

Qualitative and quantitative composition of the creams

\begin{tabular}{|l|c|c|}
\hline \multicolumn{1}{|c|}{ Ingredients } & $\begin{array}{c}\text { O/W cream } \\
\text { Amount (\%) }\end{array}$ & $\begin{array}{c}\text { W/O cream } \\
\text { Amount (\%) }\end{array}$ \\
\hline Avocado oil & 2 & 2 \\
\hline Evening primrose oil & 5 & 5 \\
\hline Niacinamide & 2 & 2 \\
\hline Shea butter & 4 & 12 \\
\hline Cetostearyl alcohol & 5 & - \\
\hline Cetyl palmitate & 4 & - \\
\hline Caprylic/capric triglycerides & 5 & - \\
\hline Cholesterol & - & 1 \\
\hline White beeswax & - & 5 \\
\hline Paraffin oil & - & 25 \\
\hline Glyceryl stearate & 2.25 & 3 \\
\hline Ceteareth-6 & - & 1 \\
\hline Ceteareth-25 & 1.8 & - \\
\hline Sepigel 305 & 1 & - \\
\hline Glycerol & 5 & 5 \\
\hline Euxyl 9010 & 1 & - \\
\hline Distilled water & 56 & 39.8 \\
\hline Sodium tetraborate & - & 0.2 \\
\hline Magnesium sulphate & - & 1 \\
\hline
\end{tabular}

\section{Creams characterization}

Viscosity analysis. Viscosity measurements were performed at $5 \mathrm{rpm}$ and $22 \pm 2^{\circ} \mathrm{C}$ by using a rotational rheometer DV-III Ultra equipped with LV-4 spindle (Brookfield Engineering Laboratories, USA). The reported results are the mean values of three measurements \pm standard deviation.
Texture analysis. Texture analysis represents a reproducible multi-parameter assessment of mechanical and structural properties of the semisolid formulations. Instrumental evaluation of creams texture was performed with CT3 Texture Analyzer (Brookfield Engineering Laboratories, USA) according to a previously described method [19]. Three measurements for each sample were recorded at $2 \mathrm{~mm} / \mathrm{s}$ test speed using Texture ProCT Software 1.5 (Brookfield Engineering Lab., USA) and the mean \pm standard deviation of the texture parameters (consistency, adhesiveness, firmness, and difficulty of spreading) was reported. The test methods used are listed in Table II.

In vivo evaluation of efficacy

In order to assess the in vivo efficacy of the two creams, an interventional, non-randomized study was carried out. The study received the approval of the Ethics Committee of the "Iuliu Haţieganu" University of Medicine and Pharmacy, Cluj-Napoca, Romania and it was carried out according to Helsinki declaration regarding Ethical Principles for Medical Research Involving Human Subjects. Prior to enrolment, each volunteer was informed about the purpose of the study, the protocol that should be followed and signed an informed consent. Biophysical characteristics of the skin were measured using Multi Probe Adapter System (Courage-Khazaka, Germany) with appropriate probes: Corneometer $^{\circledR} \mathrm{CM} 825$ (for hydration of SC) and Tewameter ${ }^{\circledR}$ TM 300 (for TEWL Index). Measurements were performed before creams application (baseline), after two-week period $\left(\mathrm{T}_{1}\right)$ and four-week period $\left(\mathrm{T}_{2}\right)$. Volunteers were kept in the test room for at least 15 minutes before the measurement; also, they were asked to follow the same skin hygiene routine and to avoid the use of other cosmetic product on tested area.

Table II

Texture analyser settings and test methods used for consistency, adhesiveness, firmness and spreadability

\begin{tabular}{|l|l|c|c|}
\hline \multicolumn{1}{|c|}{ Texture parameter } & \multicolumn{1}{c|}{ Probe } & Target value $(\mathbf{m m})$ & Trigger load $(\mathbf{g})$ \\
\hline Consistency $(\mathrm{mJ})$ & TA-DEC & 25 & 10 \\
\hline Adhesiveness $(\mathrm{mJ})$ & TA-DEC & 25 & 10 \\
\hline Firmness $(\mathrm{g})$ & TA-DEC & 25 & 10 \\
\hline Difficulty of spreading $(\mathrm{g})$ & TA-SF & 10 & 2 \\
\hline
\end{tabular}

measurements
The $\mathrm{O} / \mathrm{W}$ cream was tested on four volunteers aged between 23 and 50 years, it was applied twice a day on the hands. Volunteers with dry skin, prone to skin barrier disruption were selected, 12 measurements were performed at each time interval, on the dorsal side of the hands.

The W/O cream was tested on volunteers aged between 35 to 55 years, and it was applied also twice a day on lower part of the legs. Volunteers with very dry skin, also prone to disturbances of the skin barrier were selected, 10 measurements were performed at each time interval, on the tibial area.

\section{Results and Discussion}

Overview of the formulations

The components of the cosmetic creams were selected for the beneficial effect in restoring the skin barrier function by different mechanisms. The choice of the emollients incorporated in the creams has been made according to their rate of spreadability, but also their occlusivity to limit TEWL. Previous studies have shown that spreading properties of the emollient ingredients influence the sensory characteristics of the cosmetic product [22]. Thus, an appropriate combination of three or more emollients with low, medium, and high 
spreadability could provide a favourable sensorial profile of the cosmetic product.

In recent years, there is a growing demand for cosmetic products containing natural emollients due to the increased interest of consumers for natural ingredients and products. Evening primrose seeds oil was chosen due to its high content in essential fatty acids like linoleic $(70-74 \%)$ and linolenic $(8-10 \%)$ acids, but also in other fatty acids: palmitic and oleic acids $(6$ $7 \%)$, smaller amounts $(<2 \%)$ of stearic, myristic, oleopalmitic, vaccenic, and eicosenoic acids, and a phospholipid fraction which represents only $0.05 \%$ of the oil, represented by phosphatidylcholines $(\sim 30 \%)$, phosphatidylinositols $(\sim 27 \%)$, phosphatidylethanolamines $(\sim 17 \%)$, phosphatidylglycerols $(\sim 17 \%)$ and phosphatidic acids $(\sim 7 \%)$ [25]. Linoleic acid, as a major component of evening primrose oil, is one of the main components of ceramides from the physiological lipids, playing an important role in the proper functioning of the skin barrier [21]. Avocado oil which contains fatty essentials acids like linoleic $(6-30 \%)$ and linolenic $(0.4-4 \%)$ acids, but also oleic acid $(31-70 \%), \beta-$

sitosterol, $\beta$-carotene, lecithin, minerals and vitamins A, C, D and E, has been shown to repair dry, damaged or chapped skin [16].

Shea butter and vegetal oils have a moisturizing, nourishing, and regenerating effect on the skin [1], cetyl palmitate, and triglycerides, in addition to the emollient properties, adjust the viscosity of the cream and glycerol, is a highly effective moisturizer [1, 12]. Up to now, a wide range of studies has demonstrated multiple benefits of niacinamide on the cutaneous barrier. Niacinamide has moisturizing properties, is an indisputable adjuvant in skin diseases like rosacea and acne, but is used also for skin barrier recovery. Thus, it has been shown to increase the level of ceramides and other epidermal lipids and to promote the up-regulation of palmitoyltransferase, a key enzyme for the sphingolipid metabolism [2].

Cream characterization

Both creams had a homogenous appearance, white colour and a pleasant smell, characteristic of the ingredients. Table III presents the physical characteristics of the two creams.

Table III

Physical characteristics of the creams: viscosity, consistency, firmness, spreadability, adhesiveness. The values are reported as mean of three determinations \pm standard deviation (SD)

\begin{tabular}{|l|c|c|}
\hline \multicolumn{1}{|c|}{ Parameter $($ mean \pm SD) } & O/W cream & W/O cream \\
\hline Viscosity $(\mathrm{cP})$ & $15600 \pm 282.84$ & $12800 \pm 141.42$ \\
\hline Consistency $(\mathrm{mJ})$ & $1093 \pm 65.6$ & $277 \pm 13.3$ \\
\hline Adhesiveness $(\mathrm{mJ})$ & $24.47 \pm 2.22$ & $8.19 \pm 0.6$ \\
\hline Firmness $(\mathrm{g})$ & $36 \pm 1.3$ & $16.7 \pm 0.3$ \\
\hline Difficulty of spreading $(\mathrm{g})$ & $131.83 \pm 11.8$ & $98.3 \pm 13.4$ \\
\hline
\end{tabular}

Physical characteristics including texture parameters and viscosity are considered the most important factors in the development of cosmetic formulations, with a significant having impact on formulation performance, stability and acceptability [23]. Texture parameters were quantified using a texture analyser equipped with special probes that can penetrate the sample and record the force, distance, and time [24]. Although texture measurements are useful to describe the quality of the final product depending on raw materials and process parameters used and to evaluate the cosmetic product considering its usage, several studies show the correlation between sensory analysis and textural properties of semisolid products [17].

Conducted measurements showed higher values for all parameters in the case of $\mathrm{O} / \mathrm{W}$ cream. Consistency has an important influence on the final behaviour of the cosmetic product, higher values of consistency showing a thicker cream with lower spreadability than the W/O cream. Lower values of the consistency of the W/O cream may allow an easy pick-up from the jar, and a better ability to spread.

The rate of spreading also depends on the viscosity of the cream. Increasing viscosity of semisolid formulations enhances the retention time at the cutaneous level, but at the same time decreases the spreadability.
The value of adhesiveness was higher too for the $\mathrm{O} / \mathrm{W}$ cream, probably due to the polyacrylamide-based thickener agent. The higher adhesiveness value was correlated to the lower spreadability of the $\mathrm{O} / \mathrm{W}$ cream. However, the high adhesiveness was not perceived as negative by the volunteers who tested the cream. In vivo efficacy evaluation

A competent skin barrier regulates the SC hydration by preventing the water loss. The quality of skin barrier may be assessed through numerous methods, especially through non-invasive biophysical in vivo techniques. Among these methods, SC hydration and TEWLIndex measurement are frequently used as objective assessments to monitor variations in barrier function. SC hydration is evaluated by using corneometry method and the values are expressed as arbitrary units, while TEWL represents the amount of water that evaporates from the skin per unit area of skin per unit of time $\left(\mathrm{g} / \mathrm{m}^{2} / \mathrm{h}\right)$. An intact skin barrier is characterized by low TEWL values, while increased values indicate an impaired epidermal barrier [4, 7, 18].

During the study, all volunteers experienced an improvement of skin aspect after daily use of the creams, the results being correlated to the values of the measured skin parameters. 
In Figure 1, the influence of four-week application on skin hydration level is presented. The hydration of the skin is an important parameter because it influences not only the appearance of the skin and its comfort, but also the function of the proteolytic enzymes involved in the desquamation process. Thus, the lower the water content of the SC, the more visible are the scales.

A statistically significant increase of the skin hydration level compared to mean basal values was evidenced for both creams, after four weeks (Table IV).

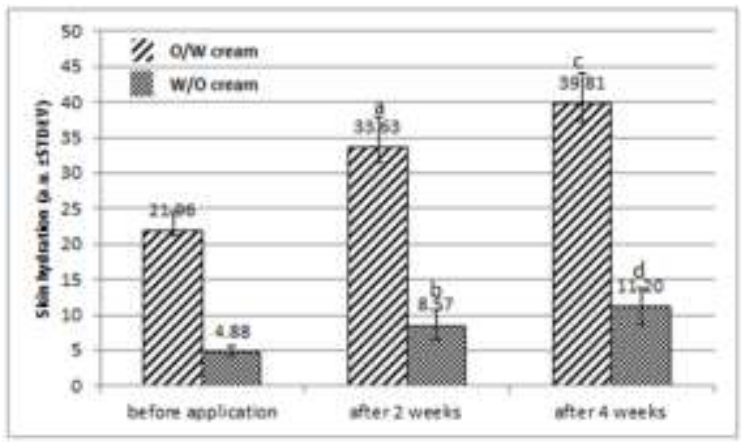

Figure 1.

Variation of skin hydration before and after creams twoweek and four-week period of application (mean \pm SD, $\mathrm{N}=12$ ); values are expressed in arbitrary units (a.u.) a-d represent statistically significant differences in skin hydration compared to baseline (paired t-test, $p<0.05$ level of significance)

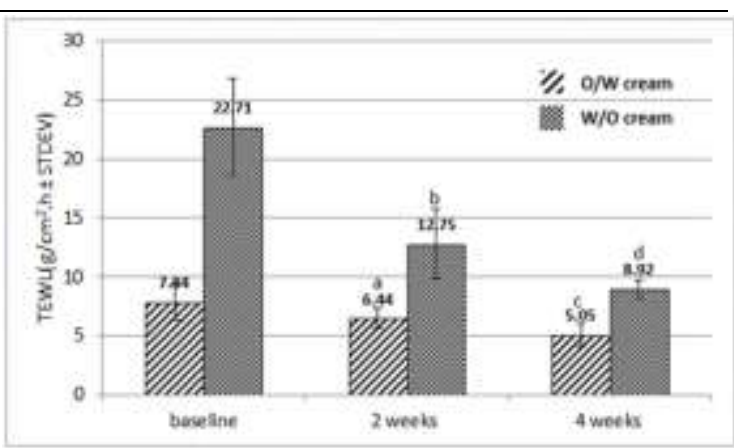

Figure 2.

Variation of TEWL before and after creams application (mean $\pm \mathrm{SD}, \mathrm{N}=12$ )

a-d represent statistically significant differences in TEWL compared to baseline (paired t-test, $p<0.05$ level of significance)

Figure 2 presents the variation of TEWL during the study. At the beginning of the study, the volunteers who tested the $\mathrm{O} / \mathrm{W}$ cream had normal skin barrier as their TEWL values were within the reference range $\left(6-10 \mathrm{~g} / \mathrm{m}^{2} / \mathrm{h}\right)$ [9]. For the volunteers who tested the $\mathrm{W} / \mathrm{O}$ cream a disturbed barrier was noticed, as it can be seen from the increased TEWL values. After four weeks, TEWL values decreased in both groups, suggesting an improvement of the skin barrier, but in regard to volunteers who used the W/O cream, a reparation of skin barrier could be observed as the TEWL values returned to normal range (Table V).

Table IV

Mean values, variation (\%) and statistical significance ( $t$-test) of skin hydration

\begin{tabular}{|c|c|c|c|c|}
\hline Product & $\begin{array}{c}\mathbf{T}_{\mathbf{0}} \\
(\mathbf{m e a n} \pm \mathbf{S D})\end{array}$ & $\begin{array}{c}\mathbf{T}_{\mathbf{4}} \text { weeks } \\
(\mathbf{m e a n} \pm \mathbf{S D})\end{array}$ & $\begin{array}{c}\text { Variation } \\
(\boldsymbol{\%})\end{array}$ & $\begin{array}{c}\boldsymbol{p} \text { values } \\
\left(\mathbf{T}_{\mathbf{0}} \text { vs. } \mathbf{T}_{\mathbf{4}} \text { weeks }\right.\end{array}$ \\
\hline O/W cream & $21.96 \pm 2.46$ & $39.81 \pm 4.35$ & +81.28 & $p<0.001$ \\
\hline W/O cream & $4.88 \pm 0.75$ & $11.20 \pm 2.53$ & +129.51 & $p<0.001$ \\
\hline
\end{tabular}

Table V

Mean values, variation (\%) and statistical significance $(t$-test) of transepidermal water loss index

\begin{tabular}{|l|c|c|c|c|}
\hline \multicolumn{1}{|c|}{ Products } & $\begin{array}{c}\mathbf{T}_{\mathbf{0}} \\
(\mathbf{m e a n} \pm \mathbf{S D})\end{array}$ & $\begin{array}{c}\mathbf{T}_{\mathbf{4}} \text { weeks } \\
(\mathbf{m e a n} \pm \mathbf{S D})\end{array}$ & $\begin{array}{c}\text { Variation } \\
(\boldsymbol{\%})\end{array}$ & $\begin{array}{c}\boldsymbol{p} \text { values } \\
\left(\mathbf{T}_{\mathbf{0}} \boldsymbol{v} \mathbf{~} \mathbf{T}_{\mathbf{4}} \text { weeks }\right)\end{array}$ \\
\hline O/W cream & $7.84 \pm \mathrm{DS}$ & $5.05 \pm \mathrm{DS}$ & -35.59 & $p<0.001$ \\
\hline W/O cream & $22.71 \pm \mathrm{DS}$ & $8.92 \pm \mathrm{DS}$ & -60.72 & $p<0.001$ \\
\hline
\end{tabular}

These results confirm the importance of using appropriate skincare products in terms of actives and delivery system in the case of dry and damaged skin, suggesting that a period of at least 4 weeks is needed for skin barrier restoring.

\section{Conclusions}

Two semisolid topical formulations, one O/W cream and one W/O cream containing niacinamide, emollient and moisturizing ingredients for restoring the skin barrier function were developed. The four-week in vivo efficacy study performed on human volunteers had shown an increase of SC hydration status and an improvement of skin barrier function for the $\mathrm{O} / \mathrm{W}$ product and restoration of the skin barrier for $\mathrm{W} / \mathrm{O}$ product, both products leading to an improvement of skin appearance.

\section{Conflict of interest}

The authors declare no conflict of interest.

\section{References}

1. Abidemi TA, Adebayo OJ, Idowu O, Nutrient content and anti-nutritional factors in shea butter (Butryospermum parkii) leaves. Afr J Biotechnol., 2009; 8(21): 58885890. 
2. Berson DS, Osborne R, Oblong J E, Hakozaki T, Johnson M B, Bissett DL, Niacinamide, in: P. K. Farris John Wiley \& Sons eds. Cosmeceuticals and Cosmetic Practice, Ltd, Chichester, UK, 2013; 13: 210-215.

3. Bogdan C, Iurian S, Tomuta I, Moldovan M, Improvement of skin condition in striae distensae: development, characterization and clinical efficacy of a cosmetic product containing Punica granatum seed oil and Croton lechleri resin extract. Drug Des Devel Ther., 2017; 11: 521-531.

4. Buraczewska BB, Lindberg M, Törmä H, Lodén M, Changes in skin barrier function following long-term treatment with moisturizers, a randomized controlled trial. British J Dermatol., 2007; 156(3): 492-498.

5. Crișan D, Moldovan M, Badea I, Avram R, Boca A, Melincovici C, Mihu C, Crișan M, Evaluation of the efficacy of antiageing and hydrating products on the cutaneous senescence process. Preliminary Data. Farmacia, 2013; 61(6): 1082-1090.

6. Darlenski R, Kazandjieva J, Tsankov N, Skin barrier function: morphological basis and regulatory mechanisms. J Clin Med., 2011; 4(1): 36-45.

7. Dimitar A, Schliemann S, Elsner P, Methods for the assessment of barrier function. Curr Probl Dermatol., 2016; 49: 61-70.

8. Draelos ZD, New treatments for restoring impaired epidermal barrier permeability: Skin barrier repair creams. Clin Dermatol., 2012; 30(3): 345-348.

9. Elias PM, Feingold K, Skin Barrier, Taylor \& Francis Group New York, 2006: 591-599.

10. Elias PM, Sugarman J, Does moisturizing the skin equate with barrier repair therapy?. Ann Allergy Asthma Immunol., 2018; 121(6): 653-656.

11. Forslind B, Engstrom S, Engblom J, Norlen L, A novel approach to the understanding of human skin barrier function. J Dermatol Sci., 1995; 14(2): 115-125.

12. Ikhuoria EU, Maliki M, Characterization of avocado pear (Persea americana) and African pear (Dacryodes edulis) extracts. Afr J Biotechnol., 2007; 6(7): 950-952.

13. Jang HH, Lee SN, Epidermal skin barrier. Asian $J$ Beauty Cosmetol., 2016; 14(3): 339-347.

14. Jabs HU, Stratum Corneum - From Corneobiochemistry to Corneotherapy. Ästhetische Dermatologie. 2013; 1: $14-19$.
15. Kim D, Park WR, Hwan Kim J, Fabrication of pseudoceramide-based lipid microparticles for recovery of skin barrier function. Colloids Surfaces B: Biointerfaces, 2012; 94: 236-241.

16. Lin TK, Zhong L, Santiago L, Anti-Inflammatory and Skin Barrier Repair Effects of Topical Application of Some Plant Oils. Int J Mol Sci., 2018; 19(1): 70: 1-21.

17. Lukic M, Jaksic I, Krstonosic V, Cekic N, Savic S, A combined approach in characterization of an effective W/O hand cream: the influence of emollient on textural, sensorial and in vivo skin performance. Int J Cosmet Sci., 2012; 34(2): 140-149.

18. Moldovan M, Ciortea L, Efficacy evaluation of different cream formulations on healthy skin properties. Farmacia, 2010; 58(6): 787-794.

19. Moldovan M, Lahmar A, Bogdan C, Părăuan S, Tomuta I, Crișan M, Formulation and evaluation of a water-in-oil cream containing herbal active ingredients and ferulic acid. Clujul Medical, 2017; 90(2): 212-219.

20. Moncriff G, Van Onsellen J., Young T, The role of emollients in maintaining skin integrity. Wounds, 2015; 11(1): 68-74.

21. Muggli R, Systemic evening primrose oil improves the biophysical skin parameters of healthy adults. Int J Cosmet Sci., 2005; 27(4): 243-249.

22. Parente ME, Gambaro A, Ares G, Sensory characterization of emollients. J Sens Stud., 2008; 23(2): 149-161.

23. Simões A, Veiga F, Vitorino C, Developing Cream Formulations: Renewed Interest in an Old Problem. J Pharm Sci., 2019; 108(10): 3240-3251.

24. Tai A, Bianchini R, JachowiczJ, Texture analysis of cosmetic/pharmaceutical raw materials and formulations. Int J Cosmet Sci., 2014, 36(4): 291-304.

25. Timoszuk M, Bielawska K, Skrzydlewska E, Evening Primrose (Oenothera biennis) Biological Activity Dependent on Chemical Composition. Antioxidants (Basel), 2018; 7(8): 108: 1-11.

26. Zhang Q, Murawsky M, LaCount T, Kasting GB, Li KS, Transepidermal water loss and skin conductance as barrier integrity tests. Toxicol In Vitro, 2018; 51: 129-135. 